\title{
Gendered Democracy: Women Teachers in Post-War Toronto
}

\author{
Kristina R. Llewellyn
}

The focus of post-war Toronto public secondary schools was the creation of a microcosm of liberal democracy, promising freedom and effective citizenship for the nation. The article explores how gender hierarchy was an implicit part of early post-war liberal "democracy" in schools. By examining women teachers' oral histories, the article discusses the discrepancy between their responsibilities as partners in the "democratic" school and their authority with specific reference to curriculum and inspection reforms of the period. The barriers of post-war educational "democracy" for Toronto women secondary teachers show clearly in the informal and localized ways they adapted this model for their everyday practice.

La priorité des écoles secondaires publiques torontoises d'après-guerre fut la création d'un microcosme de démocratie libérale, promettant liberté et une véritable citoyenneté à la nation. L’auteure de l’article étudie comment la hiérarchie basée sur le genre participa de façon implicite à cette " démocratie » libérale d'après-guerre dans les écoles. Analysant les récits de vie des enseignantes, elle examine les différences entre leurs responsabilités en tant que partenaires de l'école «démocratique» et leur pouvoir réel, en faisant spécifiquement référence aux réformes des programmes scolaires et d’inspection de la période. Les obstacles que représentait la " démocratie » éducative de l'après-guerre pour les enseignantes du secondaire de Toronto apparaissent clairement à travers les moyens informels et décentralisés qu'elles utilisèrent pour faire en sorte que ce modèle de travail fonctionne dans leur pratique quotidienne.

In 1947, Z.S. Phimister, who was Superintendent and Chief Inspector of Schools in Toronto, noted that "people turn to the school after the war...in the faint hope that the school may be able to do something which will make it possible for the next generation to avoid another calamity..." The school, particularly the secondary school, was responsible for producing intelligent, Christian, freedom-loving

$1 \quad$ Z.S. Phimister, “The Principal and the School,” The School (Nov. 1947): 103, quoted in Robert M. Stamp, The Schools of Ontario, 1876-1976 (Toronto: University of Toronto Press, 1982), 183. 
citizens and workers. ${ }^{2}$ For Toronto secondary schools, the focus in the 1950s was on creating a microcosm of liberal participatory democracy. Editors of the 1951 issue of the Ontario Secondary School Teachers' Federation (OSSTF) newsletter stated: "Only experience of life in a democratic school community can give young people the values they need and the understanding upon which to build full and happy personal lives." 3 The democratic school model focused on students, teachers, and administrators each assuming the right and responsibility to enrich the community. ${ }^{4}$ Relationships among all members were to be marked by consultation and mutual respect. During the 1950s, popularization of democracy resulted in the physical reorganization of the school, expanded access of schooling with vocational programs, and the prominence of psychology with an emphasis on child-centred learning. ${ }^{5}$

These initiatives would, theoretically, have provided teachers with the rights and freedoms to work as they deemed most effective. For women teachers, however, the appearance of the democratic school, complete with renovated open spaces and movable desks to allow for flexible lesson plans and co-operative work, did not result in democratic practice. Women teachers' narratives tell a story of 1950s secondary schools that remained highly patriarchal, centralized, and hierarchical. In the 1950s, women teachers wanted to carve out a new place for themselves in the reconstruction of the secondary school, but public policy, as informed by larger shifts in post-war Canada, was going in a different direction. In post-war Canada as a whole, there was a search for an internal defence against the uncertainties of the age caused by traumatic changes to the social, political, and economic

2 Several educational historians discuss these post-war objectives for secondary schools. See, for example, Stamp, The Schools of Ontario, 1876-1976; R.D. Gidney, From Hope to Harris: The Reshaping of Ontario's Schools (Toronto: University of Toronto, 1999).

3 E.J. Palmer, "Democracy in School Life: Report of the Schools Committee of the Association for Education in Citizenship,” The Bulletin, February 1951, 24-25.

4 Ibid.

5 Gidney, From Hope to Harris, 30. The following primary sources provide further information on educational objectives for the creation of the school as a microcosm of democracy: J.G. Althouse, Structures and Aims of Canadian Education (Toronto: W.J. Gage and Company, 1949); H.L. Campbell, Curriculum Trends in Canadian Education (Toronto: W.J. Gage and Company, 1952); J. Dewey, Democracy and Education (New York: Macmillan, 1916); Frank MacKinnon, The Politics of Education: A Study of the Political Administration of the Public Schools (Toronto: University of Toronto Press, 1960); Hilda Neatby, A Temperate Dispute (Toronto: Clark, Irwin and Co. Ltd., 1954); Hilda Neatby, So Little for the Mind (Toronto: Clark, Irwin and Co. Ltd., 1953). 
landscape. ${ }^{6}$ Social authorities were intent on containing radicalism by purporting national "togetherness" or "normality" under the banner of a liberal conception of egalitarian democracy. ${ }^{7}$ The rhetoric of democracy was everywhere, touting each citizen's rights and freedoms to participate in the country's political rule. The concept cloaked its narrow definition of freedom and effective citizenship in the period, namely, the desired norm of being English, middle class, white, and heterosexual. ${ }^{8}$

Gender hierarchy was an implicit part of early post-war liberal democracy. The post-war Canadian government sought to ensure public entitlements, including renewed social security initiatives such as health insurance, unemployment insurance, and workmen's compensation. Post-war welfarism, however, was premised on the independence of the private realm of the family, which was consigned to women as the mothers of the nation. ${ }^{9}$ By definition women were quasi-citizens and secondary workers in the public world of liberties. Men were, by contrast, long-term participants in the labour market with rights to authority and knowledge in the public world. ${ }^{10}$ Women teachers, including those who were married with children, were encouraged to participate in the "democratic" institution of the public school insofar as there existed a shortage of teachers to meet the demands of post-war baby boomers. ${ }^{11}$ Women teachers were

6 Doug Owram, Born At the Right Time: A History of the Baby-Boom Generation (Toronto: University of Toronto, 1996); Mary Louise Adams, The Trouble With Normal: Postwar Youth and the Construction of Heterosexuality (Toronto: University of Toronto Press, 1994), second chapter. A strategy of containment within the post-war period of the United States is discussed by Elaine Tyler May, Homeward Bound: American Families in the Cold War Era (New York: Basic Books, 1988). Traumatic changes included: military men returned to the workforce and often strained familial relations; women were expected to leave their positions in the workforce following the war but continued to work due to the flourishing economy; there was an unprecedented baby boom; the marketplace shifted from a producer-based economy to a consumer-focus one; there were waves of immigration; the threat of the atomic bomb was palpable and a global intelligence race was typified by the launch of the Russian satellite Sputnik.

$7 \quad$ Shirley Tillotson, The Public at Play: Gender and the Politics of Recreation in Post-War Ontario (Toronto: University of Toronto Press, 2000), 4-6.

$8 \quad$ Mona Gleason, Normalizing the Ideal: Psychology, Schooling and the Family in Postwar Canada (Toronto: University of Toronto Press, 1999), 4.

9 Tillotson, The Public at Play, 8-9.

10 Ibid., 9.

11 Alison Prentice et al., Canadian Women: A History (Toronto: Harcourt Brace Jovanovich, 1988), 351; Ontario Institute for Studies in Education of the University of Toronto, Ontario Historical Education Collection (OISE/UT, OHEC), Province of Ontario, Department of Education, Report of the Minister of Education, 1952, as quoted in Sandra Gaskell, "The Problems and Professionalism of Women Elementary Public School Teachers in Ontario, 1944-1954" (Ed.D. diss, Faculty of Education, University of 
embraced as necessary participants in the labour market of the education system as a means by which a "normal" social order could be reconstituted. Traditional gender boundaries, disrupted by the war, were still heralded as women's primary contribution to the nation's stability. In a 1952 Globe and Mail article, C.C. Goldring, Director of the Toronto Board of Education, articulated the desirable qualities of female teachers' contributions to society. He commented that "men like the motherly qualities of the kindergarten teacher, the rim lines of the physical education teachers, and the home economics teachers' skill with the skillet."12 Women teachers acted within the public and gendered institution of the school, while simultaneously being relegated to the private sphere of the home.

Feminist historians of education have long recognized that women as teachers occupied a contradictory position as leaders within a patriarchal public institution that placed their authority in question. ${ }^{13}$ This contradictory position was particularly pronounced as educational policy in the 1950s heralded an egalitarian environment, yet refused the majority of women teachers the administrative positions and political organization to control their work environments. This article explores the ways in which women teachers were afforded greater responsibilities as partners in the creation of a seemingly democratic school climate, but were not afforded the commensurate level of authority. The study focuses on the oral histories of ten women teachers who worked in post-war Toronto public secondary schools. These women's narratives speak directly to the discrepancy between responsibility and authority with specific reference to curriculum redevelopment and inspection reforms of the period. Political policies sought to abolish the days when teachers were handed down curriculum from above, and students had little flexibility in the courses required for graduation. Just as curriculum plans were meant to create

Toronto, 1989), 33 and 157. Gaskell cites the marital status of all women teachers in Ontario as, in 1941, married 5 per cent, single 92 per cent, and widowed, divorced, or separated 2.5 per cent; 1951: married 28 per cent, single 67.7 per cent, and widowed, divorced, or separated 4.3 per cent. W.J. Dunlop, the Minister of Education, stated in the 1952 Ontario Department of Education Report that one of the greatest problems facing education "is the supply of teachers...by emergency measures, it has been possible to prepare, during the year, a sufficient number of teachers to ensure that no school was closed for lack of a teacher."

12 “Cupid So Busy Can’t Get Enough P.T. Teachers,” Globe and Mail, 9 Jan. 1952.

13 See, for example, the work of feminist historians in Women Who Taught: Perspectives on the History of Women and Teaching, ed. Alison Prentice and Marjorie R. Theobald (Toronto: University of Toronto Press, 1991). 
or support the "democratic" school model, inspection procedures were revised to encourage community and personalized supervision of teachers. Teachers' efforts for self-meaning or collegial supervision would complement the external inspector, whose own role was supposed to change from cold analysis to warm encouragement. New post-war initiatives in curriculum and inspection were premised on the "democratic" school model. The barriers of post-war "democratic" rhetoric for Toronto women secondary teachers show clearly in the ways in which they adapted, accommodated, and resisted this model for their everyday practice. The interviewees' narratives illustrate that educational authorities' definitions of democratic curriculum were not necessarily liberating, so the women implemented their own pace, material, and method of teaching. The interviewees also rejected notions of post-war co-operative supervisory practices, arguing that inspections were oppositional and interfering. They recognized that they were often a part of creating hierarchical structures in the school regarding supervisory powers, as a familiar chain of command was easier to manipulate to their own needs. This form of agency does not mean women supported a gendered democracy. They worked within the gendered democracy for authority, using informal and localized powers that would enable them to exert control.

\section{Methodology: Listening to Women Teachers' Oral Histories}

The interviewees were aware that the research project was intended to explore the relationship between the power and identity of women secondary teachers and the political and cultural atmosphere of 1950s "democratic" education and the narrative strategies they utilized to articulate their historical role within the system. Questions were posed in a semi-structured interview format that addressed areas from their family backgrounds and personal interests in relation to their philosophies of education and daily workloads. Each of the anonymous interviewees taught in Toronto for at least two years during the 1950s. Participants in the study were recruited through purposive sampling, which relied on word-of-mouth chain. They had worked at one or more of the ten collegiate institutes run by the School 
Board of Metropolitan Toronto. ${ }^{14}$ They taught subjects considered to be appropriately feminine and less intellectually rigorous, such as English, modern languages, history, and physical education. Despite gender divisions by fields, and the general lack of female administrators, women were an integral part of the academic environment. ${ }^{15}$ Women teachers accounted for almost one-third of the typical thirty-five-member staff of most collegiate institutes. ${ }^{16}$ Although factors such as level of education, age, race, ethnicity, sexuality, and socio-economic status were not criteria for their participation in this research, they are nevertheless important analytical components for understanding each woman's experiences of teaching. At the time of the interviews in 2001-2002, the teachers ranged in age from their early seventies to late eighties. All of them were of white, Anglo-Saxon backgrounds, and designated themselves as middle to upper class from their family of origin or through marriage. ${ }^{17}$ The interviewees obviously do not represent the diversity of women's experiences. They are, however, representative of the typical woman teacher who was hired to work in 1950s secondary

14 In 1953, the Ontario legislature mandated consolidation of schools surrounding the Toronto area. The newly formed Metropolitan Toronto School Board included both elementary and secondary schools in the city of Toronto, the towns of Leaside and Weston, the villages of Forest Hill and Swansea, the Lakeshore district, and East York, North York, Etobicoke, York, and Scarborough townships. The newly formed Metropolitan Board was one of the largest education centres in Canada with total expenditures of over \$128,000,000 (W.T. Newnham and A.S. Nease, The Professional Teacher in Ontario: The Heritage, Responsibilities and Practices [Toronto: The Ryerson Press, 1965], 35-37). The Toronto area had over 79,000 students in 1954, including 16,896 enrolled at the secondary level: Toronto District School Board Sesquicentennial Museum and Archives, Toronto Board of Education, Year Book (Toronto: Noble Scott Co. Limited, June $\left.30^{\text {th }}, 1954\right), 12$.

15 Cecilia Reynolds, "Hegemony and Hierarchy: Becoming a Teacher in Toronto, 1930-1980," Historical Studies in Education 2, 1 (1990): 111 and 114. According to Reynolds, although women accounted for 62 per cent of all teachers in Toronto, there were only two women secondary principals at the beginning of the 1950s.

16 Statistics from the Toronto Board of Education Year Book from 1954 show that there were 754 day school secondary school teachers, including 271 women, of whom 51 were married. These statistics are not exact as many women used initials instead of Miss or Mrs.

17 All interviewees have been provided pseudonyms. Four of the ten women interviewed were married, including three with children. Phoebe McKenzie, Fran Thompson, and Melanie Kilburn were all wives and mothers during the time period under study. Karen Phillips was also married but did not have children. Marion Hayes, Elizabeth MacKay, Beth Merle, Muriel Fraser, June West, and Beverley Hurst were unmarried and did not mention a life partner during their interviews. Several of these women did mention, however, their responsibility for the care of loved ones during the period. 
schools. ${ }^{18}$ Their stories are valuable for exploring the "average" woman teacher's visions of, and position within, the education system.

The women teachers' oral histories are treated as texts founded on a knowledge base that comes complete with conflicting interpretations, evaluations, and explanations, which are intrinsic to the representation of any historical reality. ${ }^{19}$ The deconstruction of women's narratives as an unstable basis for "true" knowledge reveals the structuring paradigms and processes that shape women's individual and collective material realities in the past. Although the approaches are often contested within feminist theory, it is an integrated feminist, poststructuralist, and materialist analysis for women teachers' oral history that provides a framework to expose and destabilize essentialist tropes or myths inscribed by male dominance in education. As Joan Sangster has noted in her work on women's oral histories, post-structural analysis is beneficial in deconstructing the narrative form of scripts for meanings in women's oral histories and in acknowledging the construction of the narrative as text by both researcher and researched. ${ }^{20}$ She further comments that feminist materialist insights are needed to focus historians on examining the ways relations of power shape women's choices within social, cultural, political, and economic boundaries. ${ }^{21}$ An integrated reading reveals how school structures shaped women teachers' identities, while also demonstrating the ways women invoke cultural concepts, which are discursively

18 Patricia Anne Staton and Beth Light, Speak with their own voices: a documentary history of the teachers of Ontario and the women elementary public school teachers in Ontario (Toronto: Federation of Women Teachers' Associations of Ontario, 1987), 130. They argue that the demographics of women teachers remained fairly consistent over a long period: most were white, Anglo-Saxon, Protestant, and from lower-class to middleclass families. The main change during this period was the increase in the number of married women teaching: Reynolds, "Hegemony and Hierarchy," 111-17. Reynolds states that by 1961, 72 per cent of women teachers were British, followed by a small percentage with French and German backgrounds. The women interviewed reflect these statistics, although it is important to acknowledge that they have higher socio-economic status than indicated as "average" by Staton and Light. Furthermore, unless the women interviewees chose to discuss their sexual orientation, the question was not posed and thus statistics cannot be given for this area.

19 Kathleen Casey, I Answer with My Life: Life Histories of Women Teachers Working for Social Change (New York: Routledge, 1993), 13; Popular Memory Group, "Popular memory: Theory, politics, method," in Making Histories: Studies in history-writing and politics, ed. R. Johnson, G. McLennan, B. Schwartz, D. Sutton (London: Centre for Contemporary Cultural Studies, University of Birmingham, 1982), 205-52.

20 Joan Sangster, "Telling Our Stories: Feminist Debates and the Use of Oral History," in Rethinking Canada: The Promise of Women's History, Third Edition, ed. V. StrongBoag and A. Fellman (Toronto: Oxford University Press, 1997), 317.

21 Ibid. 
available depending on their social locations. Similarly, when openly acknowledging the complex production of oral history, historians can understand that their research priorities, such as the structure of the education system, co-exist with women teachers' priorities, such as the daily workload. An integrated analysis provides a feminist critique of oral history that encourages historians, as Marjorie Theobald puts it, to work within layers of memory, rather than beyond them. ${ }^{22}$

\section{Women Teachers' Narratives of Curriculum in the "Democratic" School}

Central to the interviewees' memories of post-war Toronto secondary schooling was the content of the courses they taught. Their stories were a reflection on educational officials' reconstitution plans for schooling which sought flexible curriculum that would be relevant to the modern world and individual student needs, rather than uniform prescribed content. In 1949, the newly appointed Minister of Education, Dana Porter, announced what is known as the "Porter Plan," for the re-organization of grades according to four ageappropriate divisions that would allow for more tailored instruction and course options. ${ }^{23}$ George Roberts, a principal and past president of the OSSTF, explained to secondary teachers in The Bulletin that flexibility might result in wrong decisions by students, but that "this, we are told, is a lesson in responsibility for democratic choice, and a risk that must be taken." 24 Teachers were supposed to act as "experts" who would guide, and not drill, students through the course content. Teachers, according to the "Plan," would work in co-operation with superintendents and principals to develop course curriculum through the establishment of local committees. ${ }^{25}$ By the early 1950s over 5,000 teachers were on 139 local curriculum development committees to revise more than 1,400 courses in 129 areas, including a number in Toronto. ${ }^{26}$ The Ontario Department of Education encouraged

\footnotetext{
22 Majorie Theobald, “Teachers, memory and oral history,” in Telling Women's Lives: Narrative Inquiries in the History of Women's Education, ed. Kathleen Weiler and Sue Middleton (Philadelphia: Open University Press, 1999), 21.

23 Stamp, The Schools of Ontario, 190.

24 George Roberts, “What Do ‘They’ Mean?” The Bulletin, Oct. 1950, 189.

25 Ibid.

26 Douglas Myers, "From Hope to Hall-Dennis: The Official Report as an Instrument of Educational Reform," in Means and Ends in Education: Comments on Living and Learning, ed. Brian Crittenden (Toronto: The Ontario Institute for Studies in Education,
} 
teachers' participation on these committees, considering that "the acceptance of the responsibility for curriculum revision provides teachers with an opportunity to reach their true professional status...group participation will give teachers practice in those democratic techniques and procedures... It will afford the opportunity for the development of democratic leadership."27

The interviewees' negotiation of the gendered tensions inherent in the post-war ideal of democracy is most clearly illustrated with respect to these curriculum development initiatives. For the women interviewed, ownership of curriculum was not a luxury, but often an extra burden in a busy work schedule. With the rapidly expanding secondary school system, the 1950s were a stressful and busy time to be a teacher. The women teachers faced increased paperwork, demands on their time for extra-curricular activities, and interference in their classroom by supervising administrators. ${ }^{28}$ The extent to which instruction was often overshadowed by a multitude of other school-wide activities is apparent in the comments of Beverley Hurst: "We did much more than just teach during the day." 29 She recalled extra help for students in the morning, supervision at lunch, no spare time for preparation, and many late nights and long weekends marking. The interviewees explained that ownership of curriculum could not be simply defined according to Ministry initiatives, as curriculum extended well beyond the classroom walls for the women teachers. Many of the women noted that their male colleagues, while also overworked, did not receive the same level of extra duties. Phoebe McKenzie recalled bringing this point to the attention of her colleagues at a staff meeting. She was agitated that the men on staff, particularly the administrators, did not supervise dances. Phoebe recalled: "I would like to know why there were no men on duty Friday night. Lots of people would like to know why neither the principal nor one of the vice-principals was on duty." 30 The women expressed a number of varied reasons for this discrepancy: specifically, administrators did not expect men to plan social events for the school,

\footnotetext{
1969), 16.

27 L.S. Beattie, “Group Planning and Teacher Participation in Curriculum Revision,” The Bulletin, June 1951, 120.

28 For more information on the workload of women teachers see, for example, Doris French, High Button Bootstraps: Federation of Women Teachers' Associations of Ontario, 1918-1968 (Toronto: The Ryerson Press, 1968), 161.

29 Interview with Beverley Hurst, 14 Dec. 2001, Toronto, Ontario.

30 Interview with Phoebe McKenzie, 16 Nov. 2001, Toronto, Ontario.
} 
men were assumed to have families so needed to get home, men often taught the sciences that did not involve as much marking as did female-dominated language-based subjects, and more often men were the administrators designating the extra duties. ${ }^{31}$ The narratives reveal that educational officials interpreted these responsibilities for women teachers as a "natural" contribution to their work in the school.

When specifically questioned on curriculum development in the traditional sense of course content within the classroom, the women teachers noted that it was a top-down process. They argued that in spite of the prescribed nature of course content, they did take initiatives to enrich the curriculum. Karen Phillips explained that the Ministry said "here are the books you are going to read this year and that's it. It was very restrictive." 32 Although Karen described the curriculum as prescriptive, she quickly noted: "It was the books and not the lessons. I covered twice as much because it was too restrictive. They had no modern stuff at all, so I introduced them to and assigned them other things to read." 33 Interestingly, the particular reading Karen used to illustrate her enrichment of the curriculum was, as she described, "about a young rebellious guy who explored."34 She did not provide the title of the book, but her message was clear: she was exploring her own rebellious ways. In fact, later in the conversation, Karen quietly discussed her bold use of a book that was, as she described it, "blacklisted." She explained: "Certain books were blacklisted from the English department or from the curriculum because of a certain influence they thought wasn't appropriate...to do with McCarthyism, communism, etc...I had all of my students read Catcher in the Rye, not part of the curriculum but they were all expected to read it." 35 While one cannot be sure in what ways she understood the book to be "blacklisted," Catcher in the Rye was not on the recommended text list from the Department of Education. ${ }^{36}$

31 For examples: interview with Phoebe McKenzie; interview with June West, 7 Dec. 2001, Toronto, Ontario; interview with Marion Hayes, 27 Nov. 2001, Toronto, Ontario. 32 Interview with Karen Phillips, 26 Nov. 2001, Toronto, Ontario.

33 Ibid.

34 Ibid.

35 Ibid.

36 OISE/UT, OHEC, Ontario, Department of Education, Text Books Approved or Recommended for Use in Elementary and Secondary Schools (Toronto: Queen's Printer, 1955); OISE/UT, OHEC, Ontario, Department of Education, Text-books authorized, approved, and recommended and instructions regarding text-books for public, separate, continuation and high schools and collegiate institutes for the school year 1950-1959 (Toronto: King's Printer and Queen's Printer, 1950-1959); OISE/UT, OHEC, Ontario, Department of Education, Courses of Study, Grade XIII English (Toronto: Queen's 
Despite her awareness of the McCarthy-era surveillance and fears of seditious activities, Karen's decision signified the bold, yet "unofficial” steps she took to control the content of her students' learning. Her story also illustrates that, while teachers were encouraged to be individuals and have a strong influence on their students, the content of the lessons taught was supposed to be patriotic in nature and thus project loyalty to the government's educational agenda.

Phoebe McKenzie similarly recounted a story in which democracy in practice did not correlate with her individual freedom to choose as a teacher. She recalled: "We got notices from the Board in the fifties to emphasize the importance of democracy. We were told to be sure to show that democracy is the preferred type of government...the democratic society is the preferred society." 37 Phoebe's memory of the notices left room for her to add her own personal knowledge, and not simply rely on the text. In response therefore, she recalled, "I taught the rise of Modern Russia. Now when we were studying communism...when we were through studying it, we had a big blackboard summary with characteristics of communism and we would fill the whole front board and part of the side board. I had my own classroom so I would leave it on. We would go over it again." 38 Phoebe, like Karen, was aware that she was crossing boundaries: "I was told that you could never do that in New York. Americans were absolutely scared skinny of Communism. Even to this day, you know, one of the reasons they don't have Medicare is that it is socialized medicine." 39 Her story is unique to the women insofar as she acknowledged that her personal politics informed the content of her lessons. Phoebe explained that trials of communists also took place in Canada during the period, and a good friend's husband was tried and imprisoned. ${ }^{40}$ Her discussion was based on the education community's heightened awareness of the persecution of communists and left-leaning teachers. Newspaper clippings of the period reveal a steady public surveillance of communist activities amongst teachers and other influential members of the education system in Toronto. Newspaper reporters cited

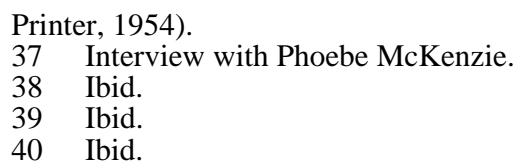


Toronto teachers who attended communist rallies, as well as the communist backings of those individuals who were running for school board seats. ${ }^{41}$

The surveillance of teachers' political affiliations partially explains why the women interviewed resisted questions that designated their actions or beliefs as "rebellious” or "defiant.” Phoebe was representative of the women insofar as she simultaneously argued that she followed the prescribed curriculum, but was also the "master of my own classroom, with my own expectations." ${ }^{\text {42 }}$ Her narrative, as with other women teachers, speaks to the contradictions that defined their position in the laboratory of democracy. As "good" teachers, the education community expected them to follow their prescribed duties, while at the same time to exhibit initiative and autonomy as professionals, and to do so within a co-operative, teamwork environment. ${ }^{43}$ The majority of the women teachers depicted subtle negotiations of this tension. Beverley Hurst, for example, repeatedly implied that the content and structure of her lesson were determined by external figures. She stated: "The department in the school and the head had textbooks. Usually you were just following the textbooks." 44 At a later point in the interview, Beverley was asked: "Did the principal or the government or you determine what happened in the classroom?"45 Without vocalizing her response, Beverley slowly raised her right-hand index finger and firmly pointed it to her own chest. ${ }^{46}$ She did not want to state that she was ultimately in charge of her own classroom because, as a teacher, she was obligated to abide by Ministry objectives. Nonetheless, she knew that she had set an agenda that would work for the pace of her class and her own workload. Mostly, the women were able to finish what they believed was necessary according to their obligations to the Ministry and their students, while still retaining some of their autonomy in their own conceptions of democratic freedom. Muriel Fraser made this

41 Examples from 1952 include: "City Teachers at Red Rally,” Telegram, 26 Sept.; "4 Communists Run For Council Posts, 4 For School Board,” Telegram, 11 Nov.; "24 Seeking 14 Seats on Board of Education," Globe and Mail, 18 Nov.

42 Interview with Phoebe McKenzie.

43 One may also surmise that the women teachers did not see themselves as defiant to authority because popular memory has designated the 1950s as a conformist period in history.

44 Interview with Beverley Hurst.

45 Ibid.

46 Ibid. 
argument when she stated: "I think I stuck to the curriculum. I think we managed to finish it well, but then I talked to them a lot about travels. You see I would go overseas, because you knew French and German...I brought in a lot of stuff. ${ }^{47}$ Typically the women teachers expressed control over curriculum development through how the content was covered and not the content per se. According to the women teachers, the emphases and pace they set were influential factors in their students' learning.

Of course, it is important not to disregard the regulations that structured the topics, timelines, and activities for teachers' lessons. In particular, most of the women noted that examinations continued to be of great influence on the curriculum. Although the 1950 Report of the Royal Commission on Education, better known as the Hope Commission, had called for a de-emphasis on examinations to allow for more freedom in the curriculum, mandatory matriculation or senior exams remained until the 1960s, and department-based general exams were the norm through the better part of the 1950s. ${ }^{48}$ Fran Thompson was just one of the women teachers who described teaching to the departmental exam. She recalled that a grade 12 exam was set by the head of the department and the vice-principal one year, and it contained "detailed questions on it about military battles that I hadn't taught. I don't think it was in the textbook." 49 Fran asserted that because examinations were taken so seriously and strictly, she believed it was unethical for her to inform students of these questions. She explained: “I was really sorry. I knew it wasn't fair but couldn't do anything about it. I didn't set the exam and there was nothing I could do." Fran reasoned her actions were justified because she was an "obedient, law-abiding person who followed the rules." Following this characterization as a "good" teacher who followed the rules, Fran recounted a story in which she was successful with her students by wandering off the beaten track of prescribed content. She acknowledged that she often wanted to teach material that was "not just textbook or set by the exam.” In one grade 9 class in which she was teaching British history, she stated: "I got on the great plague and the great fire. I knew that there were some wonderful descriptions so

\footnotetext{
47 Interview with Muriel Fraser, 1 Dec. 2001, Toronto, Ontario.

48 Report of the Royal Commission on Education (chaired by Mr. Justice Hope)

(Toronto: King's Printer, 1950), 89-90; Gidney, From Hope to Harris, 14 and 20.

49 All quotations in this paragraph from interview with Fran Thompson, 20 Nov. 2001, Toronto, Ontario.
} 
I took a whole week out of the set curriculum and taught them...They absolutely adored it but somehow or other I didn't feel I had much freedom to do that."

Fran's "feeling" that she did not have much freedom to express her personal control over the content of courses was shared by most of the women interviewees. There existed, however, distinct differences of feelings between the women who were promoted to heads or assistant heads of departments, and those who were not. Of the women interviewed, over half were promoted, which is an overrepresentation of the numbers for women generally. Promotions were given to women almost entirely within their female-dominated subjects, and did not extend to the position of principalship. Typically, the interviewees who had been promoted at some point in their careers expressed relatively greater abilities not only to insert their own ideas into the content and methods of their classes, but to do so in a co-operative and collegial environment. The interviewees who were not promoted, like Fran, argued that there was "no sharing resources between teachers, or lesson plans...no, all my teaching totally by myself." 50 June West also noted: "there wasn't coordination amongst the teachers in terms of how they were loading students...there was also not a conferring amongst teachers to have a multi-discipline approach."51 She argued, in fact, that she was glad she “wasn't a part of any team teaching because to prepare took a lot of preparation already. I was pretty much left alone to teach as I thought I should teach."52 According to many of the women who did not take on an administrative role, collaboration with colleagues either was non-existent or simply extra work.

In particular, the women who were classroom teachers asserted that administrators were interfering forces in their classes. Administrators did not provide friendly guidance, but, rather, constrained their abilities to teach effectively. June said, "The principal commented on my bulletin boards so he must have gone around after hours...Then you had your inspector reports...I had the textbooks and you're supposed to cover so much, and department heads came with the departmental exams, and your success was measured by this...you were kept on your toes." ${ }^{33}$ June's and Fran's

Ibid.

Interview with June West.

Ibid.

Ibid. 
narratives express the frustrations of teachers who considered they were under constant watch, but who also felt unsupported. In contrast, Elizabeth MacKay, a department head during the period, described a school environment in which "curriculum was my own responsibility, but you didn't have to go too far without backup...you got along well because I think there was teamwork mostly in departments...administration and teachers communicated."54 Elizabeth recalled opportunities to meet with other women teachers who were heads of physical education departments as a part of a city-wide association that would "do a lot of chatting and discussing...because of that association we moved from entirely inter-form competition to inter-school." 55 Similarly, Karen Phillips related her administrative position to her participation in initiatives that had an impact on her school and the education system as a whole. Karen expressed feelings both of relative autonomy and creative licence in her work when she recalled participating in curriculum planning sessions with the OSSTF. She described this work as "making many advances...all sorts of committees prepared booklets on curriculum." ${ }^{56}$ Karen even carried this work into creating a supportive environment for her colleagues by assisting with in-service training or educational conferences. Given Elizabeth's and Karen's confidence in affecting their school environments, it is not surprising these women recalled directly appealing to officials for greater authority. Clearly, the hierarchical structure of the school was not simply defined by gender, but existed among the women themselves. The difference in perspective is understandable as women department heads could be seen as an extension of centralized, male-dominated authorities. No issue makes this difference more vivid than discussions regarding inspections or supervision visits that evaluated teachers' instruction practices.

\section{Women Teachers' Narratives of Supervision in the "Democratic" School}

As the women's narratives reveal when discussing curriculum initiatives, educational authorities focused on effective inspection or

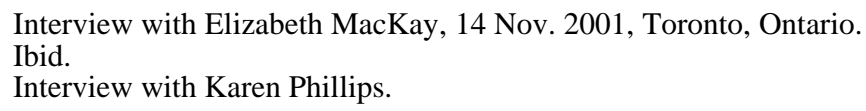


supervisory processes in post-war Toronto secondary schools. In an effort to ensure that the secondary school reflected democratic practices, educational authorities demanded changes to inspection procedures of the period. They wanted inspections to be based on friendly assistance rather than autocratic judgement. In accordance, the government permitted school boards to appoint their own municipal inspectors to provide community-based and personalized support for improving teachers' instruction. ${ }^{57}$ The well-known educator C.W. Booth elaborated on the new concept of inspection, or supervision as he referred to it, in his article in the September 1959 issue of Canadian Education. Examining aims and trends in Canadian secondary education, Booth argued that supervision had changed from "cold, critical analysis imposed from above to the present friendly, sympathetic, co-operative appraisal of daily work by supervisor and teacher for the benefit of teacher and pupils alike." 58 The prime purpose, he insisted, was for teachers to initiate self-supervision as a way to strengthen their instruction, and as an example for their students' learning. ${ }^{59}$ He concluded that "supervision at its best is a cooperative project, involving pupils, teachers, department heads, principals, superintendents, and inspectors - all working together and giving their best for the school, the community, and the nation." ${ }^{60}$ The traditional annual inspection by board-appointed specialists was becoming rare in the 1950s. As such, formal inspectors were instructed to appraise not only the work of teachers, the accommodations and equipment of the class, and the success of students, but also to examine the school's internal methods of supervision. ${ }^{61}$ Whether by way of an external or internal supervision, the rhetoric of the period framed such visits as consultative means of providing support for teachers' hard work. A Survey of Supervisory Practices of Persons in Personal Communication with Classroom

\footnotetext{
57 Henry Johnson, A Brief History of Canadian Education (Toronto: McGraw-Hill Company of Canada, 1968), 106-8.

58 C.W. Booth, "Some Basic Aims and Recent Trends in Secondary Education," Canadian Education 14, 4 (1959): 44.

59 Ibid.

60 Ibid., 45.

61 OISE/UT, Director of Education, Toronto Board of Education, Report on the experimental and newer aspects of schools work by the Toronto Board of Education, 1952, 2-3.
} 
Teachers, published by the Toronto Board, implied that "probably most supervision is provided by teachers for other teachers." 62

The women interviewed asserted that teachers never oversaw each other's classes as the survey suggested. Their assertions were based on the belief that inspections involved interference and intimidation, and were founded on a lack of trust in their knowledge as academics and their character as teachers. Inspections were not, therefore, cooperative moments. The women depicted them as oppositional incidents in which people took sides. The department head was an adversary and not a partner in the improvement of instruction. Beth Merle, a department head, explained this tension when she stated: "Well, some teachers didn't take very kindly to sharing their lessons or ideas, and as head you sometimes had to do things about lessons that you would see." ${ }^{63}$ The autonomy of the classroom environment seemed to be more sacred for the women who did not have "official" authority. The potential adversarial nature of the relationship is evident in the desire of classroom teachers for autonomy and, at the same time, the desire of department heads to demonstrate their authority. June West argued that department heads were protective, and sensitive to the potential of their role. She recalled: "One inspector I thought was not very wise, there was this one occasion where I was teaching basketball and she brought the head of the department in and was suggesting some things I was doing that the head of the department might do. Well, I didn't think that was very...it was putting me in a bad position." ${ }^{4}$ Women department heads were in a position that afforded them greater powers than the classroom teacher. These powers were far less, however, than those of the male principals, inspectors, and superintendents to whom they were responsible.

For different reasons, therefore, all of the women interviewed remembered tension-filled encounters with external inspectors who came into their classrooms. The women characterized inspections as "nervous," "intimidating," and "bad."65 The inspector was there to point out weaknesses in teachers' performances. Essentially,

62 OISE/UT, Toronto Board of Education, A Survey of Supervisory Practices of Persons in Personal Communication with Classroom Teachers (Toronto: Toronto Board of Education, 1961), 1.

63 Interview with Beth Merle, 23 Nov. 2001, Toronto, Ontario.

64 Interview with June West.

65 Interview with Elizabeth MacKay; interview with June West; interview with Muriel Fraser. 
inspectors graded their performance in a way similar to an elementary school report card with categories ranging from skills to relationships, and ratings from superior to unsatisfactory ${ }^{66}$ Evaluations included a range of items from the women's appearance to the content of their classes. The women teachers, like the Ontario Teachers' Federation, argued that the inspector was not contributing towards democracy in practice by assisting the teacher to be a self-sufficient evaluator. The lack of this intention is evident as inspectors rarely spoke to the teachers about their instruction techniques, and provided the written evaluation only to the principal of the school. Elizabeth MacKay explained: "You probably got inspected about once a year. They might tell you they would like to come into your class at such and such a time or they might just walk in. They may give comments, but they usually just walked out."67 Muriel Fraser commented with sarcasm about the inspection visits: "It was always a great day when the inspector came around. It made you nervous and you knew you were up for inspection and you tried your best. Then there would be a great get together afterwards between the inspector and the principal. They may come around at the end of the day and say what they thought."68

Considering the nature of these visits, the OTF made recommendations to the Hope Commission that "a copy of the Inspector's annual report on each teacher should be made available to the teacher concerned." 69 They recommended as well that suggestions for improvement be made to the individual teacher and that the practice of grading be discontinued. ${ }^{70}$ The relationship between inspector and teacher remained however a distant one, with the teacher often unaware of the complaints the inspector may have made to educational officials. This made the power of the inspector somewhat elusive to the women teachers interviewed. A number of the women associated negative inspector reports with a lack of promotion, no increments in yearly pay, and the denial of permanent certificates of teaching. For example, Fran Thompson made regular threats to quit her job based on an inspector's refusal to approve her for a permanent

66 W.D. Douglas (Member of the Supervision and Inspection Committee of the OSSTF), “The Principal and Supervision and Inspection,” The Bulletin, 31 May 1957, 141-42.

67 Interview with Elizabeth MacKay.

68 Interview with Muriel Fraser.

69 Gaskell, "Problems and Professionalism of Women Elementary Public School Teachers,” 90.

70 Ibid., 91. 
certificate, and thus higher pay and more job security, until her instruction abilities were evaluated at a senior grade level. ${ }^{71}$ Phoebe McKenzie explained: "If you taught successfully for two years, the inspector would decide to sign your certificate. That meant you had your permanent certificate., ${ }^{\text {,2 }}$ The inspector obviously used and asserted his power over teachers and not with them. According to the women interviewed, this relationship existed despite the fact that the Toronto Board took initiatives to improve inspections. The association of supervisors, in consultation with principals, inspectors, and male and female teachers, undertook a survey of teachers to understand the dynamics of such communications. ${ }^{73}$ Not surprisingly, the survey, which began in 1959, found that teachers wanted to know the aims associated with supervisor's criticisms, as well as to have visual and verbal demonstrations of any changes they demanded. ${ }^{74}$

The women teachers interviewed may have agreed with such recommendations in principle, but they argued in their narratives that the inspectors' suggestions were essentially useless and inconsequential to the improvement of their instruction techniques. They held this opinion generally because the inspectors were men who pontificated about their expertise in teaching matters, but were oblivious to the subject specialty of the women they observed. Beverley Hurst diminished the inspector's authority when she explained: "We never worried too much about those chaps because they were Maths and Physics people and they didn't really know...they wouldn't really understand the make-up of the lesson the way they would in Science and Math. I mean they were nice people but..."75 Beverley was clearly implying that the prestigious authority of male educators' knowledges from the sciences did not impinge on her authority over knowledge in female-dominated subjects such as languages. Fran Thompson similarly recalled inspectors as administrative types who were out of touch with the classroom and effective teaching techniques for student learning. She illustrated this point by retelling a story about a Friday afternoon in which a "whitehaired man... an inspector came in and sat during the first half of my class, then he left his seat and did this extraordinary noisily, energetic

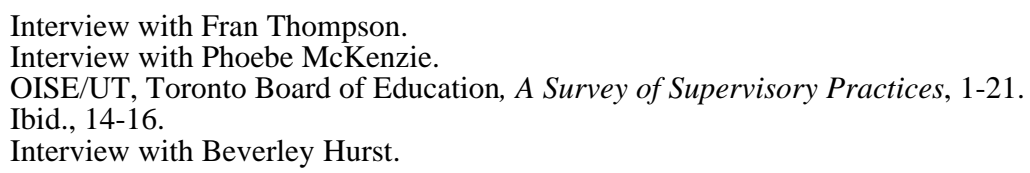


thing where he fired off questions."76 The inspector as she recalled thought she needed "more pep to get the kids excited about all this...he made a big thing about it...fire a question here, fire a question there...make that person answer."77 Fran stated that "wasn't my style. I quietly taught things and if you didn't put your hand up, I didn't ask you." "8 Fran laughed, with great satisfaction, at what the students said on Monday, "We don't know what that guy was doing. Do you mind if we go back over the lesson we did on Friday?"79

The majority of the women believed that, despite the potential for negative reports, the inspector was of no consequence to their teaching. As a group, they painted a picture in which they "humoured them" by showing the inspectors what they wanted to see, but then continued to teach in ways that they deemed most effective. It began, as June West noted, with teachers secretively letting each other know that the inspectors were in the school so they could prepare their lessons accordingly. June remembered: "Someone in the office would know the inspector arrived and would get the book and pass it to the teachers. That was the signal when the book got passed around and the teachers would pass it to each other." ${ }^{\text {"0 }}$ Marion Hayes' and Beth Merle's narratives confirm this rendering of events, as they both recalled teachers putting on lessons for the inspector that were polished and practised from years past. Marion explained: "You got to know what some of them liked. Then, of course, you got these people that they said taught the same lesson every time but I don't know." ${ }^{11}$ Beth, like Marion, implied that these secretive practices occurred, but she did not directly associate herself with these activities. She stated: "I know of teachers who always taught the same lesson for inspectors. The kids knew it." 82 Lessons for inspectors were not only insider conspiracies between teachers, but also with students. As Muriel Fraser noted, "You made a special effort for that day. I used to talk to the kids and explain what was going on and they would rally around. They always behaved for those days." 83 Teachers, students, and even office workers seemed to support each

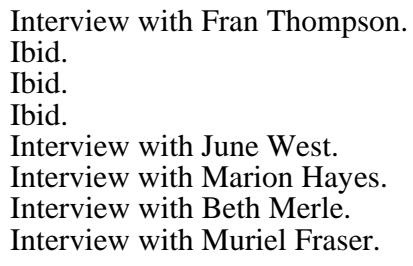


other in defining the classroom as a place where the teacher would determine the practices and not some external observer. After all, as Phoebe McKenzie concludes the story in her narrative: "I'm going to tell you something. If there is going to be any improvement in education, it is going to be right in the classroom. The greatest value in the whole educational system is a darn good teacher in the classroom." 84

With the determination and resolve of these teachers in actions and beliefs, it might be hard to understand why they did not seek more radical demands for access to supervisory roles, such as promotion to principal or inspector. For some, promotion was interpreted as the only other way to gain greater power in the structure of the school, and this option was closed to most women. Without identifying her own desire for promotion in her career, June stated: "Now they have the opportunity. Then they didn't, so there was no point in wasting energy on that." ${ }^{85}$ For others, it may have been fear of accusations of disloyalty, during the hyper-patriotism of the period, which influenced the teachers toward a more subtle expression of dissatisfaction with official doctrines. In part, however, a number of the women teachers agreed with a quasi-hierarchical power structure in the school. A firm pecking order, from their perspective, meant that at least they knew the rules they could quietly negotiate. Many of the women teachers spoke of their principals with respect and admiration when they characterized them as "a benevolent dictator," or "military-like, who ran a tight ship." ${ }^{86}$ Muriel Fraser described the principal with whom she worked in the 1950s as an "ex-World War One colonel...a very strong wonderful man" who "ruled with an iron hand. He sent out daily orders and told us to 'kill your own snakes' ", ${ }^{87}$ Muriel laughed as she remembered the principal. For her, as with the other women interviewees, principals who ruled in such a way had a healthy respect for teachers' autonomy in the classroom, while at the same time clearly demonstrating that they were the ultimate decision-makers. Many of the women, considered this hierarchical organizational structure, in which each member fulfilled strictly defined duties, to be beneficial because it meant that principals stayed in their administrative offices and out of their classrooms. At the same time,

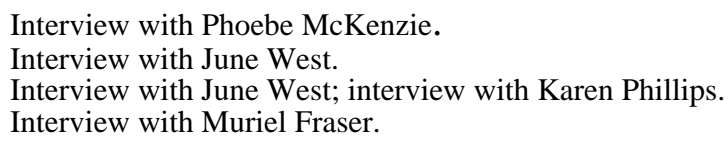


it provided a clear example to students that the teacher was the commander of the classroom, whom they needed to respect. The hierarchical structure of the school was thus both beneficial and detrimental to the woman teacher. She had to negotiate the tensions between upholding an inequitable school structure and seeking its collapse.

The women teachers brought this authoritarian structure into the classroom. Beth Merle was proud of the fact that her students were "scared to death" of her oral examinations in French. ${ }^{88}$ To her, this translated into students following her orders, like the principal, as the ultimate supervisor in the classroom. Few of the women teachers recalled embracing initiatives that would provide a more independent, "democratic" learning environment for their students. They implied that they participated in the production of a democratic school in another important way. They did so insofar as they did not focus on selfish pursuits for greater powers of supervision, and thus authority. Instead, they asserted that their teaching was a vocation or a service to others. Some women used the term vocation, and others simply noted that they "always wanted to teach," or "it was in my blood." ${ }^{9}$ The school, for them, was not a place in which one scrambled to climb the ladder of success while knocking over others in the process. The perception that teachers wanted to work for money or possibly power, both of which were provided to the male-dominated positions of inspector and principal, was abhorrent to the post-war democratic ideal of individual pursuits for the community benefit. J.G. Althouse, Chief Director of Education for the Ontario Department of Education, stated to a graduating class of student teachers in the mid-1950s that "service is something he would willingly do for nothing." 90 Educational officials considered other goals to be particularly repugnant for the woman teacher whose professional commitment was already in question, as her priorities were still idealized as wife and mother, or at the very least an example to students of demure and calm post-war femininity. Karen Phillips, who was promoted to department head, explained her promotion as part of this broader vocational spirit: "The head of the English department, the man, dropped dead at school. I

\footnotetext{
88 Interview with Beth Merle.

89 Ibid; interview with Beverley Hurst; interview with Marion Hayes.

90 J.G. Althouse, Addresses: A Selection of Addresses by the Late Chief Director of Education for Ontario, Covering the Years 1936-1956 (Toronto: W.J. Gage Limited, 1958), 200.
} 
had unofficially helped him doing things in the department. So I guess the principal at that time knew he could count on me. They didn't need any more problems." ${ }^{\prime 1}$ The interviewees lacked a language with which to discuss their desire for more power or control within the post-war education system. Furthermore, tactics associated with union activism or public displays of dissatisfaction were, for the women interviewed, politically untenable and, even more, destructive to the negotiation of a workable authoritative position in the "democratic" post-war secondary school of Toronto.

THESE WOMEN asserted that they were able to control the variables they deemed to be immediately important to their teaching experiences, namely, the content and methods of their teaching. They readily declared, however, that there were greater battles to be won in order to gain official equality for women that would match a level of authority with their responsibility. To make these changes, according to the post-war rhetoric of liberal democracy, women teachers would have had to gain visibility in the public realm. Given the gendered hierarchy of this political ideology, women had limited agency from which to exact such power. The women teachers' narratives demonstrate, nevertheless, that the notion of liberal democracy, which attempts to disguise norms of inequality, is vulnerable to the "powers of the weak." ${ }^{2}$ They were able to exercise power, not typically through formalized means, but informal and localized means. Despite describing the failure of the Toronto secondary school as a microcosm of practical democracy, they expressed a sense of empowerment and ownership over curriculum and supervision. The interviewees' perceived powers as women teachers varied, of course, according to the boundaries they perceived for appropriate behaviour. As such, their stories and experiences expose the inscribed gendered ideologies of the teacher. For the women included in the study, their relationship to, and powers within, the education system would have been drastically different had they not come from white, middle-class, welleducated families. The women teachers interviewed, however, were not extraordinary. They were neither conservative nor progressive, neither hero nor villain, neither typical nor atypical: they were

91 Interview with Karen Phillips.

92 Tillotson, The Public at Play, 159-60. 
ordinary - ordinary in the sense that they illustrated life as it was understood, interpreted, and practised on a daily basis, and not according to odd moments of political upheaval or civil disturbance. It is this ordinariness of their knowledges, languages, and identities that is the most influential in the make-up of our social institutions and, in part, our historical consciousness.

Too few studies have examined the historical effects of the everyday for women in education. This silence can be partially attributed to teachers' unique status. Labour historians have overlooked teaching because it stands between the working and professional classes, and many feminist scholars have ignored teaching to examine more groundbreaking occupations like law and medicine. ${ }^{93}$ The studies that have been completed in the Canadian context tend to be grand narratives of the development of education systems and teaching as a profession. ${ }^{94}$ More selective works that address women tend to focus on the feminization of teaching as it relates to the development of bureaucratic structures in the nineteenth century, or the formal organization of women elementary teachers and their quests for professional recognition. ${ }^{95}$ Little is known about the work of the "average" woman secondary school teacher in the mid-twentieth century. This gap in the historical record can also be attributed to the continued success of liberal ideology in conveying the idea that the public realm is a marketplace for the free exchange of ideas. The women teachers' narratives demonstrate that public institutions regularly privatized women's voices. It is in responding to the feminist agenda to unmask the process of privatizing women's experiences in a "democratic nation" that this study takes a critical theoretical approach. As Kathleen Weiler notes in Women Teaching

93 Kate Rousmaniere, City Teachers: Teaching and School Reform in Historical Perspective (New York: Teachers College Press, 1997).

94 See, for example, C.E. Phillips, The Development of Education in Canada (Toronto: W.J. Gage and Company Ltd., 1957); J.G. Althouse, The Ontario Teacher, 1800-1910 (Toronto: W.J. Gage Ltd., 1967).

95 See, for example, Marta Danylewycz, Beth Light, and Alison Prentice, "The Evolution of the Sexual Division of Labour in Teaching: A Nineteenth-Century Ontario and Quebec Case Study,” Histoire sociale - Social History 14, 31 (1983): 81-109; Marta Danylewycz and Alison Prentice, "Teachers, Gender and Bureaucratizing School Systems in Nineteenth Century Montreal and Toronto," History of Education Quarterly 24, 1 (1984): 75-100; Gaskell, "Problems and Professionalism of Women Elementary Public School Teachers"; French, High Button Bootstraps; Mary Labatt, Always a Journey: A History of the Federation of Women Teachers' Associations of Ontario, 1918-1993 (Toronto: Federation of Women Teachers' Associations of Ontario, 1993); Staton and Light, Speak with their own voices. 
for Change, critical theorists acknowledge that schools are settings in which people can "assert their own experience and contest or resist the ideological and material forces" they encounter there. ${ }^{96}$ The women teachers in this study employed seemingly mundane, everyday resources to create their own meaning of educational democracy in the post-war reconstruction of Toronto secondary schools. It is this ability to exact change that most of them claimed at the end: "You would love teaching, it can be exciting”; "Try teaching...you can really make a difference there." 97

The author thanks Cecilia Morgan, Elizabeth Smyth, Jean Barman, and Alison Prentice, and the anonymous reviewers of HSE, for their thorough and beneficial readings of earlier drafts of this article. The author also extends sincere appreciation to the women who shared their stories of love for and frustration about teaching in post-war Toronto. This research was supported by a Social Sciences and Humanities Research Council Doctoral Fellowship.

96 Kathleen Weiler, Women Teaching for Change (South Hadley, Massachusetts: Bergin \& Garvey, 1988), 11.

97 Interview with Beth Merle; interview with Beverley Hurst. Phoebe McKenzie, Elizabeth MacKay, and Karen Phillips made similar statements. 